FORMATION OF A MEDICAL ASSOCJATION IN BUCKINGHAMSHIRE.

To the Editor.-Sin,-I have to inform you that at a very numerous meeting of medical practitioners at Buckinghamshire, and of several of the adjoining counties, assembled at Aylesbury on the 28th of May, for the purpose of considering the degrading imposirions practised on the profession under the auspices of the PoorLaw Commissioners, and to devise the means of redress, it was resolved to form a "Buckinghamshire Medical Association," with a view to uphold the respectability and promote the general interests of the profession; and that a Committee should be appointed to collect information as the groundwork of a petition to both Houses of Parliament, on the subject of the grievances arising out of the medical arrangements of the Poor-Law Administrators, and as the basis of a memorial to the Commissioners. It was also resolved to establish a correspondence with other Associations formed for the same purpose. -I have the honour to be, sir, your obedient servant,

Robert Ceeity, Hon. Secretary. Aylesbury, June 15th, 1835.

\section{MR. LANE AND SIR BENJAMIN BRODIE.}

\section{To the Editor of THE LANCET.}

Sir, - In consequence of certain calumnious statements which appeared in the Medical Gazette of last week in which my name has been studiously implicated with some anonymous communications relating to the affairs of St. George's Hospital, and published at various times in THE LA NCET, may I request, as bearing directly on this subject, the insertion of the inclosed correspondence between Sir Benjamin Brodie and myself, and that you will further allow me this opportunity of repeating my assertion, that I have never written, or been privy to, any anonymous communication whatever in Tre LA NCer or in any other journal? I am, Sir, your obedient humble servant,

June 16th, 1835 ;

1, Grosvenor-place.

"To Sir B. Brodie, Bart., Sapille-row.

"Sir,-Having been informed that you were under the impression that I had circulated statements which were false, and which were detrimental to your character, I waited on you on Thursday, the 2nd instant, for the purpose of removing such impressions. I then declared to you, as I do now, that I had no participation, directly or indirectly, in any such statements, or in the appearance of any anonymous letters or communications in any journal at any period whatever; and that I had no knowledge whatever of the authors of any one of them, either before or after thcir publication, and you avowed your disbelief that I had any participation in them. With this assurance, Sir, as far as you are concerned, I should have been perfectly satisfied; but 1 find that the reports by which you were misled have reached others, and that they are still circulating, to the scrious injury of my character and present professional views, and this with some for whose opinion I have the highest regard. I trust, Sir, you will see that I should be wanting in respect to myself did I not request an early disavowal from you in writing of your belief in such reports; and I should feel further obliged if you would refer me to the authors of these aspersions by which you and others have been misled; but if you think right to decline granting this part of my request, I feel assured you will do me the justice to make such persons acquainted with my disavowal and your entire disbelief of their unfounded calumnies. I have the honour to be, Sir, your obedient humble servant,

"Samuti Lane. "1, Grosvenor-place, Oct. 4th, 1834."

"To S. Lane, Esq., No. 1, Grosvenor-place. "Dear Sir,-From what you said to me on Thursday last, I am satisfied that certain ahsurd aud calumnious statements respecting some of my friends and myself, which have appeared of late in a periodical publication (or rather which I understand so to have appeared, as 1 have never read nor even seen them), were not put forth either by yourself or with your concurrence and approbation. I have already thought it but fair to you to express thus much to some of my friends. Beyond this, I do not see that $I$ can do anything towards contralicting the reports to which you allude. I have never been concerued in propagating them; and indeed, to the very best of my recollection, I have never said so much on the subject as I said to Dr. Wilson and yourself a few days ago, to any other indi idual.

"Neither can I refer you to the real authors of these reports; and $I$ much doubt whether it would be possible to trace them to any particular person. Certainly my own notions were founded, not on any specific piece of information which I had receired, but on the con- 